\title{
POLITICAL RENT-SEEKING IN PUBLIC PROCUREMENT: EVIDENCE FROM THE ENTRY OF POLITICAL CHALLENGERS AT ELECTORAL THRESHOLDS
}

Ján Palguta
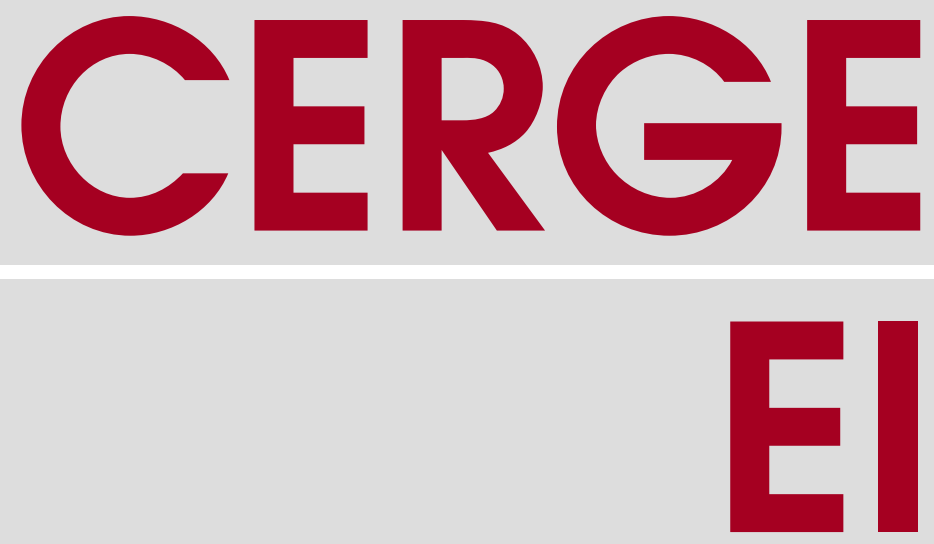


\section{Working Paper Series 549 (ISSN 1211-3298)}

\section{Political Rent-Seeking in Public Procurement: Evidence from the Entry of Political Challengers at Electoral Thresholds}

Ján Palguta

CERGE-EI

Prague, September 2015 
ISBN 978-80-7343-356-7 (Univerzita Karlova v Praze, Centrum pro ekonomický výzkum a doktorské studium)

ISBN 978-80-7344-351-1 (Národohospodářský ústav AV ČR, v. v. i.) 


\title{
Rent-Seeking in Public Procurement: \\ Evidence from the Entry of Political Challengers at \\ Electoral Thresholds*
}

\author{
Ján Palguta
}

\author{
CERGE-EI ${ }^{\dagger}$
}

\begin{abstract}
This paper shows that political challengers affect rent-seeking in public procurement. I use data from municipal governments in the Czech Republic to construct new measures of political rent-seeking in procurement and test whether the entry of additional challengers into municipal legislatures affects the rent-seeking practices. Because the entry of challengers is endogenous to the performance of incumbents, I predict the challenger entry using quasirandom variation in the vote share of challengers near the threshold in proportional elections. I show that legislatures with additional challengers allocate fewer procurements to political donors, double price savings in procurement and use more competitive procurement auctions. The entry of extra challengers leads to greater economic benefits in legislatures with fewer political parties and in legislatures entered by local-level political movements. My findings highlight the role of local-level movements in enhancing political accountability and the value of monitoring the behavior of politicians.
\end{abstract}

Key words: procurement, rent-seeking, accountability, challengers, proportional elections

JEL classification: D72, H57, H72

\footnotetext{
* I would like to thank Jana Cahliková, Luboš Cingl, Randall Filer, Patrick Gaule, Štepán Jurajda, Klára Kalíšková, Erik Meyersson, Nikolas Mittag, Elena Paltseva, Filip Pertold, all participants of the Summer School on Political Economy and GDN RRC Workshop in Prague for their helpful comments and insightful suggestions. My thanks further belong to Petr Janský and Jiři Skuhrovec, who shared data about political donors with me. A large part of this research was conducted during the author's stay at the Stockholm Institute of Transition Economics (SITE) at the Stockholm School of Economics. This visit was financially supported by Charles University in Prague. This research has further financially benefited from a grant from the CERGE-EI Foundation under a program of the Global Development Network, from GAUK grant 188915 from Charles University and from grant TD020099 from the Technological Agency of the Czech Republic. All opinions expressed are those of the author and have not been endorsed by CERGE-EI, GDN, TACR or Charles University. All errors remaining in this text are the responsibility of the author.

${ }^{\dagger}$ Center for Economic Research and Graduate Education - Economics Institute (CERGE-EI), a joint workplace of Charles University in Prague and the Economics Institute of the Czech Academy of Sciences. Address: Politickych veznu 7, 11121 Prague, Czech Republic. Email: jan.palguta@cerge-ei.cz
} 


\section{Introduction}

Corruption and political rent-seeking distort resource allocation all over the world. Growth and economic development slow down as politicians prop up inefficient firms and redirect resources from their most productive uses (Murphy, Shleifer, and Vishny 1991, 1993). Political rent-seeking can be detrimental to public service provision as contracts go to firms allied to politicians rather than to firms with the best price-quality solutions. The extent of this waste can be substantial; in OECD countries alone, governments redistribute $13 \%$ of GDP through public procurement systems (OECD 2013).

In democratic theory, elections are the tool which screens and disciplines politicians (Manin, Przeworski and Stokes 1999). If voters can oust corrupt incumbents from their office, the availability of information about politicians' behavior promotes accountability and constrains political rent-seeking (Ashworth 2012; Barro 1973; Besley and Case 1995; Ferejohn 1986; Ferraz and Finan 2008, 2011). The threat of removing corrupt incumbents can be, however, only credible if some political challengers stand up for the elections and actively seek support from voters. The disciplining effect of challenger entry has been under-explored in the existing literature, as almost all the existing models consider completely passive challengers, so the models overlook the key tasks that challengers perform, such as revealing and criticizing the incumbent's performance (Ashworth and Shotts 2011).

This paper contributes to the existing literature by providing evidence that the entry of political challengers into legislatures causally promotes political accountability and disciplines rent-seeking behavior of politicians. In particular, the paper shows that the entry of additional challengers reduces wasteful misallocation of resources in public procurement - as legislatures with additional challengers allocate fewer procurements to political party donors. Importantly, the paper identifies the disciplining effect of a challenger entry separately from electoral selection effects which would otherwise bias estimation (Alt, Bueno de Mesquita, and Rose 2011; Gagliarducci and Nannicini 2013; Gordon and Huber 2007).

The greatest empirical challenge is, in particular, that the entry of political challengers cannot be treated as exogenous (Aghion, Alesina, and Trebi 2004; Trebbi, Aghion, and Alesina 2008). Since voters elect politicians in free and democratic elections, challengers' entry is likely 
correlated with unobservable preferences of voters. This paper therefore exploits variation in the vote share of political parties near the entry threshold in proportional (PR) elections. If sufficiently close to the threshold, a part of seat allocation can be considered to be as good as random, then the legislatures with some challenger scoring close enough to either side of the threshold can be viewed as equal in all aspects, except for a disproportionally higher chance of a new challenger entry above the threshold (Lee 2008; McCrary 2008; Pettersson-Lidbom 2008; Ferreira and Gyourko 2009; Folke 2014). As a result, any observed differences in accountability on opposite sides of the threshold can be attributed to the disciplining effect of the additional challenger winning at least one seat in the legislature.

I apply this empirical strategy to a novel dataset connecting information about elections, public procurements and, uniquely, about political party donors from a large number of municipalities in the Czech Republic. In this country, political favoritism in procurement and shadow financing of political parties are viewed as major threats to economic growth and democracy (Transparency International 2012; World Economic Forum 2011). The negative phenomena are mirrored in a series of anecdotal corruption cases described by the media (Economist 2011, 2013). This paper makes use of objective measures of performance and political rent-seeking in procurement rather than perceptions or anecdotes.

The estimates in this paper demonstrate that legislators select political donors as procurement suppliers less often when additional challengers enter legislature. The legislatures with additional challengers achieve twice higher price savings in procurement and make their auctions more open and competitive by attracting more bidders. The disciplining effects are pronounced in legislatures with fewer political parties, smaller population and when political challengers are from locally-organized political movements. The overall procurement process is not impaired by the new challenger entry as comparably-sized procrements in a comparable overall volume are allocated irrespective of the entry of challengers. All validity tests provide strong support for causal interpretation of the results.

In previous literature, the entry of political challengers produced inconclusive predictions for political accountability. Moral hazard models in the spirit of Barro (1973) and Ferejohn (1986) predict that challengers will discipline the incumbents' behavior only if the difficulty of return to office increases with the entry of challengers. 
Moreover, challengers can also play an informational role in elections. They can directly reveal information on the behavior of incumbents (Ashworth and Shotts 2011) and the very fact of challengers' candidacy indirectly informs voters that the incumbent has underperformed (Gordon, Huber, and Landa 2007). However, challengers may not always have proper incentives and ability for monitoring incumbents (Kunicova and Rose-Ackerman 2005). If challengers seek to enter into coalition with the incumbent, challenger entry may actually dissolve accountability.

Empirical cross-country studies likewise deliver inconclusive evidence. Persson, Tabellini and Trebbi (2003) show that low barriers to political entry (which are expected to produce more challengers) are associated with less corruption. In contrast, Tavits (2007) finds that a high number of political parties leads to higher corruption due to low clarity of responsibility in coalitional governments. As opposed to cross-country studies, this paper uses variation in challengers' entry originating from within one country. I can therefore isolate the effect of challenger entry from institutional factors which are typically highly correlated in crosscountry studies, such as barriers to political entry or cultural norms.

The most closely related paper is perhaps Gordon and Huber (2007), who find that incumbent judges running for reelection in competitive elections are more responsive than judges who are appointed in non-competitive retention systems. The authors attribute this finding to the effect of monitoring by challengers. In contrast to Gordon and Huber (2007), this paper compares behavior of politicians within one institutional setting, where challengers either barely exceed the electoral threshold or barely fail to exceed it. This paper therefore does not suffer from potential problems of selection of more responsive types of politicians into more competitive systems. Furthermore, I manifest that the actual entry of challengers into legislatures matters for political accountability as well as the pure threat of being replaced in elections.

The last strands of related literatures estimate economic returns to political connections (Faccio 2006; Fisman 2001; Khwaja and Mian 2005) and the extent of corruption in public procurement (Bandiera, Pratt, and Valletti 2009; Di Tella and Schargrodsky 2003; Mironov and Zhuravskaya 2012; Straub 2014). This paper complements and adds to these literatures. 
The rest of the paper is organized as follows. Section II describes the electoral and public procurement systems in the Czech municipalities. Section III considers the theory behind proxies for political accountability. Section IV follows giving details of the empirical strategy. Section V introduces data on public procurement, elections and political donations. Section VI presents results and section VII gives specification and validity tests. Section VIII deals with particular mechanisms of the political challenger entry effect. Section IX summarizes and derives conclusions.

\section{Institutional Background}

\section{Municipal electoral system in the Czech Republic}

In the Czech municipal elections, members of approximately six thousand legislatures are elected directly for four-year terms. The elections are proportional (PR) with a 5 percent entry threshold, which is an important element in the identification strategy, as exceeding the threshold is a strong predictor of party entry into legislatures. ${ }^{3}$

The elections involve multiple national-level parties, local-level 'movements' and individual candidates. Political subjects draft candidate lists on their own, subject to the rule that the maximum number of candidates on each candidate list can be only as high as the number of seats in the legislature. The legislature size is proportional to the population living in the municipality and ranges from 5 to 55 legislators (Jurajda and Münich 2014).

The electoral system is an open-list system where voters can split votes across party lines using preferential votes. More specifically, voters may (but do not have to) mark one preferred candidate list, which is equivalent to marking all candidates on that list. Alternatively, the voters may mark preferred individual candidates across candidate lists. The total number of preferential votes is equal to the number of legislators if the voter does not mark any preferred list and it equals to the number of legislators minus one, if the voter marks a preferred list and then also individual candidates.

The open-list elections create a direct link between the individual performance of politicians and their re-election incentives (Persson and Tabellini 2000). The incentives for mutual

\footnotetext{
${ }^{3}$ The allocation of seats is determined using d'Hondt's method, which does not guarantee a seat to every party above the threshold.
} 
monitoring are reinforced in the open-list system, especially in elections with small district magnitude, as is the case of the Czech Republic (Chang and Golden 2007). ${ }^{4}$

Nevertheless, because political accountability does not depend only on the incentives for mutual monitoring but also on politicians' ability to exercise oversight (Kunicova and RoseAckerman 2005), the section continues with the description of the regulatory structure of the Czech public procurement.

\section{Municipal procurement in the Czech Republic}

Public procurement constitutes one of the largest spending processes in the Czech Republic. Yearly, about $13-16 \%$ of GDP (USD 31 billion in 2010) is spent on procurement of goods, construction works and services, making it one of the largest procurement markets among OECD countries (OECD 2013). Municipalities form a substantial fraction of the procurement market as they spend $8 \%$ of GDP each year, while more than $5 \%$ of GDP goes directly on municipal procurement.

Czech public procurement has often been criticized for a high prevalence of political corruption and a lack of effective institutional oversight. The World Economic Forum (2011) ranked the Czech Republic as low as 123rd among 142 countries in terms of the extent to which government officials show favoritism toward well-connected firms. The Czech constitution moreover directly prohibits the Supreme Auditing Office, the institution that audits procurements of the central government, from auditing municipal spending for reasons of fiscal decentralisation. The other institution that oversees public procurement, the Czech Antitrust Office, has been known for its rather passive and formalistic approach (Transparency International 2009).

The primary responsibility for allocation and monitoring of municipal procurements lies with politicians elected into the municipal legislatures. The members of the legislatures make direct executive decisions that concern the planning of procurements, selection of suppliers and realization of procurement projects. The legislators can therefore largely influence outcomes and conditions in the procurement, such as the competitiveness of procurement auctions, price savings achieved in procurement and the selection of procurement suppliers.

\footnotetext{
${ }^{4}$ The legislature size in the Czech Republic is lower than 15 seats in $80 \%$ of municipalities in the sample.
} 
Legislators can inspect procurements both during and after the contract-allocation process (Císařová and Pavel 2008). If the legislators perceive a risk of mismanagement or embezzlement of public funds, they can voice their concerns publicly, typically in the media or in their political campaigns. Political agents outside the legislatures face many obstacles in obtaining information about the procurement. These barriers to information include, for example, administrative, financial and time constraints. The entry of political challengers into legislatures therefore facilitates monitoring of municipal legislators because it reduces the barriers to information about the behavior of politicians in public procurement.

\section{Electoral Accountability and the Entry of Political Challengers}

Two important issues arise in determining the effect of political challengers on accountability. The first difficulty is how to reliably proxy accountability, which is a complex concept with many unobservable dimensions. The existing studies which focus on accountability can rarely show direct evidence of bribery and theft of public resources, because of the obviously secretive nature of corruption. ${ }^{5} \mathrm{~A}$ growing body of literature therefore rather tries to provide indirect evidence of rent-seeking behavior. This subfield of academic forensic economics uses changes in economic incentives to show that institutional rather than cultural factors play an integral role in determining corruption prevalence (Zitzewitz 2012).

In this paper, I follow the approach of forensic economics and proxy changes in political accountability using evidence from public procurement. I consider the following simple theoretical setup.

In my setting, politicians seek to maximize wealth and support from voters in elections. To attract finance, some politicians solicit political donations from firms. In exchange, politicians provide preferential treatment in procurement to their donors once they get elected to office. The preferential treatment can take various forms, for example, of a higher likelihood of receiving procurements, blocking fierce competition from other firms in procurement or elevated procurement prices. Dealing with politicians is, however, a risky business for firms, because politicians may not get elected to office and may not succeed in securing preferential terms for their donors. Similarly, politicians enter a risky deal because detection of their rent-

\footnotetext{
${ }^{5}$ Important exceptions include, for example, Di Tella and Schargrodsky (2003); Ferraz and Finan (2008), (2011); Reinikka and Svensson (2004) and Olken (2007).
} 
seeking is associated with costs. These can be either monetary, such as sanctions or legal fees, or political, such as a decrease in the probability of re-election. Voters namely prefer politicians who do not behave opportunistically because their utility decreases when public resources get diverted for private gains of politicians and donors.

Since the electoral chances of each political subject increase as the chances of other subjects decrease, parties benefit from monitoring each other and from revealing the rent-seeking behavior of other politicians. Some parties may not, however, want to attack other parties, because mutual attacks may damage the current or future coalitions and thereby ruin access to rents and power of each of the party involved. Nevertheless, I conjecture that if I observe a lower likelihood of allocating procurements to political donors after a quasi-random entry of new political challenger into legislature, then it cannot be explained by any reasons other than higher political accountability due to the entry of new challengers.

At the same time, due to rent-seeking behavior of politicians, procurement prices may be elevated so that the created surplus can be split among politicians and their donors. For this reason, I test whether procurements in legislatures with additional challengers are allocated at lower prices compared to legislatures without the new challengers. Nonetheless, I need to consider alternative explanations for low prices. For example, the entry of challengers can force politicians to split the rents among a larger number of involved political agents. Procurement prices may be low, but if the overall level of municipal spending simultaneously rises, the low prices cannot be interpreted as more accountable behavior. Similarly, one needs to inspect the planned size of procurements to establish whether low prices are not due to the reduced content of procurement projects. ${ }^{6}$

Finally, I conjecture that more accountable legislatures should not try to restrict competition in procurement only to a limited number of firms, but rather make procurement open for any suppliers. ${ }^{7}$ I test this prediction by comparing the number of firms in procurement auctions organized by legislatures with and without additional challengers, respectively.

\footnotetext{
${ }^{6}$ In this paper, I consider procurements on construction works where the planned size of procurements comes from external project architects. These experts use standardized norms to estimate the planned value of each procurement project based on a list of components in the project. The planned value of procurement should therefore very closely match the planned content of procurements (Pavel 2013).

${ }^{7}$ There is a large debate in the procurement literature as to which of the more or less restrictive auction formats is more effective at selecting optimal contractors (e.g. Manelli and Vincent 1995; Bajari and Tadelis 2001). I
} 


\section{Empirical Strategy}

The second issue in estimation is the likely endogeneity of the entry of challengers. To explore this concern, one can consider estimating the following naive relationship:

$$
\mathrm{Y}_{l, \mathrm{t}+1}=\mathrm{B} X_{l, t}+\beta(\text { Challenger_Entry })_{l, t}+u_{l}+\varepsilon_{l, t+1},
$$

where $\mathrm{Y}$ is the inspected outcome, Challenger_Entry indicates the entry of a challenger, $\mathrm{X}$ is a vector of covariates, $u$ is an unobserved component (e.g., the preferences of voters), and $\varepsilon$ is an error term. Subscripts $t$ and / are time and legislature subscripts, respectively.

Because voters select politicians in free and democratic elections, the important concern in estimating (1) relates to the likely correlation between voters' preferences and the entry of challengers. If $\operatorname{cov}($ Challenger_Entry, $u) \neq 0$, the OLS estimates of the additional challenger entry effect on accountability will be biased.

Nevertheless, the attractive feature of PR elections is that the entry of political subjects into legislatures is tied to a fixed minimum requirement on vote share. The electoral threshold therefore creates a discontinuous relationship between the vote share of political parties and their likelihood of entering legislature. If one can assume that political parties close enough to the electoral threshold exceed the entry requirement as well as randomly, then one can use regression discontinuity $(\mathrm{RD})$ design to estimate the challenger entry effects on accountability in an unbiased manner. Similar RD methods have been used in political economy, for example, by Lee (2008), Lee, Moretti, and Butler (2004), McCrary (2008), Pettersson-Lidbom (2008), Ferreira and Gyourko (2009), and recently by Folke (2014) with application to PR elections.

Figure 1 visually inspects the relationship between the vote share of parties and challenger entry. The left subfigure shows that roughly $75 \%$ of all parties that barely cross the threshold win at least one seat in legislature. No seat can be won if a party scores below the threshold. The discontinuity translates into a jump in the number of parties in legislatures, as shown in the right subfigure. The number of parties in legislatures jumps from an average of 5.5 parties to almost 6 parties once the party that is the closest to the threshold exceeds 5 percent. ${ }^{8}$

\footnotetext{
assume that more accountable politicians will tend to opt for more competitive and transparent auctions, even if this may mean less efficient allocation of procurements from an overall welfare perspective.

${ }^{8}$ Alternative measures of challenger entry include, for example, the number of seats allocated to a party scoring the closest to the threshold and the share of seats allocated to a party out of all distributed seats. Both options use the same source of variation in challenger entry and display the same discontinuity at the electoral threshold.
} 
As Figure 1 illustrates, the electoral threshold does not predict party entry perfectly. If that were the case, it would be sufficient to assume the continuity of covariates at the threshold to identify the causal effect of the additional challenger on the examined outcomes. One would merely need to compare the average outcomes in legislatures where the challenger closest to the threshold barely exceeded the threshold with the average outcomes in legislatures where some challenger scored barely below the threshold. Nonetheless, for the d'Hondt's method for seat allocation may not in some cases attribute seats even to challengers that exceeded the threshold, one needs to use regression-discontinuity in a fuzzy form in the estimation (Angrist and Lavy 1999; Hahn, Todd, and van der Klaauw 2001; Imbens and Lemieux 2008; Lee and Lemieux 2010; van der Klaauw 2002).

Since the probability of challenger entry gradually increases only over a range above the threshold, one needs to use data outside of this range to estimate the baseline relationship between the additional challenger entry and the inspected outcomes. The instrumental variables (IV) technique is used to estimate this baseline relationship, where instruments consist of higher-order non-linear terms of the vote share of a challenger scoring the closest to the threshold. These higher-order terms are included in the control function.

The outlined IV technique can be implemented as follows. The outcome equation is assumed to take the following form:

(2) $\quad Y_{l, t+1}=B X_{l, t}+\beta_{1}(\text { Challenger_Entry })_{l, t}+f($ Vote_sh $) \phi+u_{l}+\varepsilon_{l, t+1}$,

where $Y$ is the inspected outcome, $X$ is a vector of pre-determined covariates, Challenger_Entry captures the challenger entry, $f$ (Vote_sh) is the control function of the order of $q, u$ is the unobserved effect, and $\varepsilon$ is the error term.

The first-stage equation is then assumed to be given by:

$$
\text { Challenger_Entry } y_{l, t}=\Gamma X_{l, t}+\gamma_{1} \mathbf{1}[\text { Vote_sh } \geq c]_{l, t}+f(\text { Vote_sh }) \phi+\gamma_{2} u_{l}+\eta_{l, t} \text {, }
$$

where $\mathbf{1}[$ Vote_sh $\geq c]$ is an indicator equal to one if a challenger closest to the threshold exceeds $5 \%$ and zero otherwise, and $\eta$ is the error term. Other variables are as before.

One drawback of the outlined IV approach is that it relies on knowing the functional form of the baseline relationship between the vote share and the inspected outcomes. If, for example, the relationship is highly non-linear and one would specify it as linear, the estimates may 
simply pick up the underlying non-linearities (Jacob and Lefgren 2004). In this paper, this concern is addressed by cross-validating the proper order of the control function.

As an alternative, I use a semi-parametric approach to try to obtain consistent estimates of the challenger entry effects. This approach consists of disregarding observations outside of a narrow bandwidth of the threshold and estimating the IV regressions without the control function. This method helps assess the robustness of the parametric approach because estimates from parametric and semi-parametric approaches should be similar - provided that the control function was specified correctly. The only difference can concern a higher sampling variability of the semi-parametric approach.

The RD design nevertheless identifies the average causal effect only "locally" (Hahn et al. 2001), that is, only for legislatures where the additional challenger scored close enough to the threshold. One needs to carefully consider whether the estimated local average treatment effects (LATEs) are externally valid even for observations further away from the threshold or for observations in a different institutional setting.

The final concern is that political parties may be able to manipulate their vote share relative to the threshold based on factors correlated with the inspected outcomes. In such a case, the exclusion restriction embodied in the assumption that the binary indicator $\mathbf{1}[$ Vote_sh $\geq c]$ is correctly excluded from the outcome equation, would not be valid. To examine the assumption of challengers crossing the threshold as well as randomly, one needs to inspect the continuity of the assignment variable at the threshold. This can be done using McCrary's (2008) density discontinuity test. Moreover, this paper inspects continuity of numerous covariates at the threshold, which importantly include the number of political subjects running for elections and the number of political subjects on coalitional candidate lists. If the observable covariates are continuous at the threshold, parties should not be able to sort into legislatures and one should be confident in interpreting the estimates in a causal manner. ${ }^{9}$

\footnotetext{
${ }^{9}$ According to Folke (2014), sorting of political parties into legislatures is less likely in a proportional electoral system, given that the allocation of seats is not automatic at the entry threshold.
} 


\section{Data}

The primary data originate from the Czech register of public procurements, where information about procurements is mandatorily published if a contract-allocation process is governed by the Public Procurement Act. The database therefore mandatorily contains information about procurements that are larger than some minimum planned value. ${ }^{10}$ From this register, I draw information about all public construction procurements awarded by the municipal legislatures between the 2006 and 2010 municipal elections. Altogether, these data correspond to over 8,700 procurements, worth CZK 195 billion (approximately USD 10 billion).

The procurement data include detailed information about the contractual price and planned value of procurements, unique IDs of municipalities and contract-awarded suppliers, and information about the number of suppliers participating in procurement auctions, which I use to proxy the competitiveness in procurement.

I merge the procurement data with information about the political subjects running for the 2006 municipal elections. The electoral dataset contains information about the vote shares of all political subjects and the resulting allocation of seats in all municipal legislatures in the Czech Republic. The datasets are merged for 1,198 out of over 6,300 legislatures. I cannot match the data only in cases of very small municipalities which did not award any construction procurements during the sample period. ${ }^{11}$

I complement the data with unique information about pre-electoral donations from procurement suppliers to political parties. This information is available from the Czech Parliament and had to be manually typed into electronic form. The data cover all political donations made by firms within a one-year period before the 2006 elections. I select preelectoral donations because in this period the firms could not have adjusted their donations according to the eventual entry of challengers. The data on donations, however, can be merged only with suppliers which eventually won public procurements. The identity of other firms, which participated in procurement but did not win, is not available in the data.

\footnotetext{
${ }^{10}$ The minimum planned value for collecting data about procurements was CZK 6 million in the sample period. This is far below the average planned size of procurement, as shown in Table 1.

${ }^{11}$ I assess the continuity of multiple municipal covariates to ensure that sample selection is not an issue near the electoral threshold. Furthermore, I disregard the information about several large cities with multiple electoral districts from the dataset, such as the capital city of Prague.
} 
Finally, I add the information about municipal fiscal policies and descriptive characteristics to the dataset. This information is important for inspecting the changes in the overall municipal spending and for inspecting the continuity of municipal characteristics around the threshold. These data come from the Czech Ministry of Finance and Czech Statistical Office.

\section{Summary statistics}

Summary statistics of the final dataset are provided in Table 1 . The table starts by showing the procurement outcomes, the fiscal outcomes and it finishes with the descriptive covariates. According to Table 1, the average procurement makes up a substantial part of the municipal budget. In particular, the average procurement is worth CZK 19.5 million in its planned value and the average annual municipal budget expenditure is CZK 95.39 million. The average savings in procurement, which I calculate as the price rebate, reach 8 percent of the planned value of procurement. The contractual price paid to procurement suppliers was therefore 8 percent on average lower than the projected value of procurement. The average number of suppliers participating in procurement was 5.63 firms.

Notably, Table 1 shows that allocation of procurements to political donors is pervasive. The table shows that procurements are on average associated with CZK 16.35 thousand worth of pre-electoral political donations. This variable serves as the main proxy for political rentseeking in this paper because it can grow only when additional procurements are allocated to pre-electoral donors. The variation in political donations is substantial. No procurements were allocated to political donors in $74.6 \%$ of municipalities in the sample. On the other hand, some municipalities awarded so many procurements to political donors, that the sum of all procurement-related donations reached hundreds of thousands of CZK.

Regarding fiscal policies, I find that the average municipal budget revenue (CZK 94.19 million) only slightly exceeds the average budget expenditure (CZK 95.39 million). The average budget deficits are therefore on average only 1 percent of the municipal budget revenue.

The rest of the variables are covariates. The table shows that municipalities have on average 4.55 thousand inhabitants. Per 1,000 inhabitants, 5.73 political subjects run for the elections. These political parties can win on average 13.75 seats in the legislatures. Coalitional candidate lists near the electoral threshold are exceptional, as Table 1 shows that candidate lists which scored the closest to the threshold consisted on average of only 1.04 parties. The table finally 
shows the average age of the elected politicans, the average number of female representatives and the average number of representatives from national-level parties. These figures suggest that the elected politicians are on average 46.49 years old. Women win on average 3.33 seats in legislatures, which corresponds to $24.22 \%$ of the distributed seats. Finally, the candidates from national-level parties win on average 6.7 seats, which corresponds to $48.73 \%$ of the average number of seats in the legislatures.

\section{Results}

\section{Descriptive outcomes near the electoral threshold}

Table 2 starts the section of results by comparing the average outcomes below and above the electoral threshold, respectively, in a restricted sample that includes only legislatures where some party scored within a 2-percentage-point bandwidth around the threshold, i.e. in the range of $[0.03,0.07]$ of the vote share.

The table indicates that if some challenger scored in a legislature just above the threshold, the procurements in this municipality were associated with political donations which were $43 \%$ lower compared to legislatures where a challenger scored just below the threshold. This means that the procurements are allocated much less frequently to political donors in legislatures with additional challengers. At the same time, legislatures with an additional challenger achieved twice as high price rebates in legislatures without the additional challenger. The differences in the procurement-related donations and rebates are significant at the $5 \%$ level. The differences in other outcomes are not significant, although legislatures with the additional challengers seem to attract more suppliers into their auctions.

Similar results are visualised in Figures 2 and 3. In particular, Figure 2 uses kernel-weighted local polynomial smoothers (with $1 \%$ bandwidths) to plot the outcomes in municipalities with a challenger just below and just above the threshold respectively. Figure 3 plots the covariates using the same method. Overall, the figures suggest a very beneficial impact of the additional challenger on procurement outcomes and a very limited impact on the planned value of procurements, budgetary outcomes and covariates. However, because these results do not take into account whether challengers near the threshold are eventually allocated any seats in legislatures, this section continues with the parametric 2SLS specification, which can correct for the actual entry of challengers. 


\section{Results from 2SLS specification}

Table 3 presents the estimates of the main 2SLS specification of public procurement and fiscal outcomes on the additional challengers entry (i.e. equations (2) and (3)). The estimation procedure takes into account a full set of pre-determined covariates and a quintic control function $(q=5)$ suggested by the cross-validation procedure. ${ }^{12}$ The table also reports evidence from the first stage, which stresses the predictive power of the used instrument.

Columns (1) - (4) in Table 3 show that the entry of additional challengers improves procurement outcomes along several dimensions. First of all, the challenger entry leads to allocation of fewer procurements to firms which were the donors of political parties before the elections. In particular, column (1) shows that procurements awarded by legislatures with the additional challenger are associated with CZK 29,200 less donations compared to procurements awarded by legislatures where some challenger barely failed to enter. The estimated effect corresponds to $63.2 \%$ lower procurement-related donations. Because these donations can decline only if procurements are less often awarded to political donors, this result suggests that the optimality of procurement allocation is less often distorted when the additional challenger enters legislature. The estimate is significant at a $5 \%$ level.

Column (2) in Table 3 further demonstrates that procurement price savings are 6.8 percentage points larger when some additional challenger enters legislature. The magnitude of the effect corresponds to a $107.9 \%$ increase in rebates in comparison to legislatures without some new political challenger. The result is significant at a $10 \%$ level.

Twice as high price rebates, however, do not necessarily imply more accountable behavior. Low prices could be a sign that procurements have smaller content. At the same time, low prices can be consistent with more political parties splitting larger budgets. Column (3) therefore supports the hypothesis of greater accountability by showing the impact of additional challenger entry on the planned size of procurements which approximates the content of procurements. The estimates show that higher rebates are not associated with a simultaneous drop in the planned size of procurements. This means that higher rebates are driven by the allocation of procurements at lower contractual prices. Columns (5), (6) and (7)

\footnotetext{
${ }^{12} \mathrm{As}$ the order of the control function increases, the post-estimation F-tests from the first stage regression indicate that the quartic and quintic terms are jointly significant $(F=4.21)$ at the $5 \%$ significance level, while the sextic and septic terms are not jointly significant $(\mathrm{F}=2.74)$ at the $5 \%$ level of significance.
} 
further show that the increase in price rebates is not associated with simultaneous changes in municipal budget revenues, expenditures and budget deficits, respectively. This evidence suggests that the entry of challengers does not lead to overall higher municipal spending. The presented evidence at the same time suggests that the entry of an additional challenger does not impair the procurement process. Comparable procurements in comparable overall volume are allocated by legislatures irrespective of the entry of additional challengers.

Finally, Table 3 shows the evidence that competition in procurement increases due to the additional challenger entry. In particular, column (4) shows that legislatures with one additional challenger attract $12.9 \%$ more bidders into their auctions. The wider participation of suppliers implies either less restrictions for entry of suppliers into procurement auctions or a greater trust in the fairness of the procurement process. Either way, the result is in line with the expectation that more accountable politicians should try not to restrict the competition between suppliers to only a limited number of firms, but rather make procurement open for any suppliers. The estimated effect is significant at a $10 \%$ level.

\section{Specification and Validity Tests}

Because a major concern in parametric regression discontinuity design is a correct specification of control function, this section starts by evaluating the robustness of parametric 2SLS estimates by estimating the additional challenger entry effects semi-parametrically. In particular, Table 4 considers only legislatures where the vote share of the political party closest to the threshold fell within a 2-percentage-point bandwidth around the threshold. The 2SLS estimation procedure does not include any covariates and control function, as they should be irrelevant in semi-parametric estimation. The estimates from parametric and semiparametric approaches should be similar if control function is correctly specified in parametric approach.

Table 4 depicts the results of semi-parametric estimation. The estimated additional challenger entry effects are remarkably similar to those obtained in the parametric estimation. The results are also significant at comparable levels of significance. The striking similarity of the estimates provides a strong support for the main parametric specification.

The issue of proper specification of the control function is addressed also in Table 5, which in columns (1) - (4) shows the estimates from the parametric 2SLS specification with cubic, 
quartic, quintic, and hexic functional form of the control function ( $q=3 ; q=4 ; q=5 ; q=6$ ) respectively. The table illustrates that the magnitude of the estimated effects remains stable with respect to the choice of the functional form. In particular, panel A demonstrates stable challenger entry effects on procurement outcomes. Panel B finds consistently no effects on fiscal outcomes. Higher orders of control function therefore seem to sufficiently pick up the baseline relationship between the vote share of parties and the inspected outcomes.

The crucial assumption for validity of the fuzzy RD design is that challengers near the threshold exceed the threshold as well as randomly. The testable implication of this assumption is that one should not be able to predict the vote share of the political parties close to the threshold by any observable covariates. This indirect validity test is conducted as follows: a regression of an indicator $\mathbf{1}[$ Vote_sh $\geq c]$ which equals one if a party closest to the threshold exceeds the threshold and zero otherwise is run on the pre-determined covariates and control function. Afterwards, a statistical test whether the covariates can predict the position of the political party with respect to the threshold is conducted.

Table 6 presents the results of this validity test. The coefficient estimates on all covariates are not individually different from zero and also not jointly, as can be seen from the F-statistic of 0.92 with a corresponding $p$-value of 0.492 . The covariates therefore cannot predict whether the challenger near the threshold will exceed the threshold. This provides a strong support for claiming that parties near the threshold exceed the threshold as well as randomly.

The same conclusion of quasi-randomness also follows from McCrary's (2008) density discontinuity test, which can be used to test for undesirable sorting of political parties into legislatures. The concern is that challengers near the threshold could be involved in some sort of electoral fraud or try to form strategic electoral coalitions to exceed the entry requirement. This type of sorting would represent a problem for causal interpretation of the estimates if it sorting was based on characteristics correlated with the inspected outcomes.

The McCrary's test is implemented in Table 7, particularly as a Wald test of the null hypothesis that there is no discontinuity in the vote share of political parties at the entry threshold. I inspect both the continuity of the vote share of all political parties running for the 2006 municipal elections and of the vote share of all parties having scored the closest to the $5 \%$ threshold in respective municipalities. 
Table 7 finds no evidence of discontinuity in the density distributions of the partisan vote share. This finding is consistent with the notion of fair and democratic elections where political subjects near the threshold cannot manipulate their vote share relatively to the threshold.

Finally, the last condition for causality is the continuity of pre-determined covariates at the threshold. I test this assumption in Table 8 using a series of placebo tests, which try to detect challenger entry effects on covariates already determined before the entry of challengers. No significant results are to be found if the covariates are continuous at the threshold.

Table 8 confirms the prior that the entry of challengers cannot predict any of the observable covariates. In particular, it cannot predict municipal population, the number of seats in legislatures, the number of political parties running for elections, the number of members on coalitional candidate lists near the threshold, the average age of elected representatives, the number of elected women and also not the number of representatives from national-level parties. These characteristics seem to be continuous at the electoral threshold, reinforcing the support for the assumption of continuity of all covariates at the threshold.

In conclusion, based on the outcomes of a multitude of specification and indirect validity tests, this paper cannot reject that challenger entry near the threshold can be viewed to be as good as random. These results strongly support causal interpretation of the estimates.

\section{When the Entry of Challengers Matters More}

If the entry of political challengers promotes accountability, the factors which influence both the probability of entry and the level of accountability may increase the relevance of new challengers. For instance, if political representation already includes many political parties,

the entry of new challengers is expected to count less in explaining the variation in accountability. Likewise, the impact of new challengers may be less pronounced in more populous municipalities, because the challengers are individually less important in larger legislatures. Furthermore, the challengers in larger legislatures can free-ride on monitoring performed by other political parties. Finally, if citizens feel compelled by the behavior of incumbents to establish their own local-level political movement, the entry of these extra challengers may discipline the behavior of politicians more strongly, compared to the legislatures entered by national-level parties which operate in a majority of municipalities. 
Analyzing the mechanisms behind the challenger entry effect is important for evaluating the external validity of the main estimates. In this paper, I consider three separate channels of the challenger entry effect. First, I estimate how the entry of political challengers affects the accountability when political entry is interacted with the number of political subjects in the legislatures. As the second channel, I consider municipal population size interacted with the entry of challengers. Finally, I estimate the challenger entry effects separately for samples divided according to the type of political subjects entering legislatures. I namely consider samples where challengers near the threshold are organized either on the local level or on the national level, respectively. For estimation, I use the 2 SLS procedure as in equation (2) and (3) adjusted for the interactions described above. Table 9 shows the results of this analysis.

In accordance with the theoretical expectations, Panel A shows that the disciplining effect of the challenger entry is much smaller when political entry is interacted with the number of political parties in legislatures compared to the main results in Table 3, which do not consider interaction effects. The entry of challengers therefore matters less in legislatures with more political parties. Similarly, Panel B reports that the impact of challenger entry is much smaller than the main estimates in Table 3 when challenger entry is interacted with the municipal population size. Finally, Panels $C$ and $D$ find a much larger effect of the additional challenger entry on the allocation of procurements to political donors, if the entering political party is a locally-organized political movement rather than a nationally-organized political party.

Altogether, the results suggest that political challengers are more important for accountability when the incentives for mutual monitoring among politicians are stronger, such as in municipalities with few parties or in small legislatures. The results are furthermore consistent with the expectation that locally-organized political movements can serve as an important constraint on rent-seeking and stand as an important source of political accountability. 


\section{Conclusion}

Which political agents can best constrain rent-seeking behavior of politicians? This paper has examined the impact of entry of additional political challengers into municipal legislatures on the rent-seeking behavior of politicians in public procurement. Because political representation cannot be treated as exogenous, the paper exploited quasi-random variation in the vote share of political parties near the electoral threshold in PR representation system to be able to predict the entry of additional challengers into legislatures. Using data on public procurement, elections and political party donations in municipal governments from the Czech Republic, the paper could isolate the disciplining effect of challengers' entry on political accountability from the electoral selection effects.

The results in this paper show that the legislature entry of political challengers causally promotes political accountability and discourages legislators from rent-seeking behavior in procurement. The legislatures with additional challengers restricted allocation of procurements to political donors so that the procurements were associated with $63.2 \%$ less pre-electoral political donations compared to procurements from legislatures without the additional challengers. At the same time, the legislatures with additional challengers doubled price savings in procurement and attracted $12.9 \%$ more suppliers into their procurement auctions. All these improvements in the optimality of procurement allocation, procurement efficiency and competitiveness were achieved without changes in the planned content of procurements, additional budgetary requirements or changes in observable demographic and political covariates. The results were pronounced in legislatures with fewer political parties, in smaller municipalities and if the political challenger was a locally-organized political movement. Importantly, political parties were not found to sort into legislatures or to form strategic electoral coalitions to exceed the legislature entry requirement. The results are robust to a variety of econometric specifications and all the performed validity tests strongly suggest causal interpretation of the results.

It is important to note that the estimates still bear a LATE interpretation (Hahn et al. 2001). For the results originate from a country with open-list elections, the link between the performance of politicians and re-election incentives may be stronger in this paper compared to other countries with closed-list elections (Persson and Tabellini 2000). The legislators in closed-list systems are often more accountable to political parties which nominated them and 
less to voters. Hence, the impact of the additional challenger on accountability may not be as strong in the closed-list elections. Similarly, the estimates are dependent on other features of the institutional setting. It would be interesting, and challenging at the same time, to find out what the challenger entry effects are in more salient environments, such as for example in national legislatures. The impact on accountability might be also different in countries with a different cultural attitude towards political rent-seeking and corruption.

Given the results, it is natural to ask whether electoral thresholds should be reduced or eventually abolished and generally whether barriers to political entry should be lowered. Although Persson, Tabellini and Trebbi (2003) show that factors that lower barriers to political entry are associated with less corruption, this paper is unable to test whether a decrease in the electoral threshold would produce the desired effect of greater accountability. The employed research design can only compare the behavior of politicians in legislatures with and without additional challengers, respectively. The paper cannot predict, for instance, how politicians would behave if thresholds were halved or entirely cancelled. Moreover, the excessive fragmentation of political representation might become a concern if the electoral threshold was to be abolished (Tavits, 2007). A low clarity of governmental responsibility and the difficulties in finding agreements in fragmented legislatures might reduce the overall quality of governance in the long run. To sum up, despite finding that political challengers can constrain political rent-seeking, further research is needed to assess whether the entry of political challengers also affects other aspects of governance and ultimately improves voters' welfare. 


\section{References}

Aghion, Phillipe, Alberto Alesina, and Franseco Trebbi, "Endogenous Political Institutions," Quarterly Journal of Economics, 119 (2004), 565-612.

Alt James, Ethan Bueno de Mesquita, and Shanna Rose, "Disentangling Accountability and Competence in Elections: Evidence from US Term Limits," Journal of Politics, 73 (2011), 171-186.

Angrist, Joshua, and Victor Lavy, "Using Maimonides' Rule to Estimate the Effect of Class Size on Scholastic Achievement," Quarterly Journal of Economics, 114 (1999), 533-575.

Ashworth, Scott, "Electoral Accountability: Recent Theoretical and Empirical Work," Annual Review of Political Science, 15 (2012), 183-201.

Ashworth, Scott and Kenneth Shotts, "Challengers, Democratic Contestation, and Electoral Accountability," APSA 2011 Annual Meeting Paper, 2011.

Bajari, Patrick, and Steven Tadelis, "Incentives versus Transaction Costs: a Theory of Procurement Contracts," RAND Journal of Economics, 32 (2001): 387-407.

Bandiera, Oriana, Andrea Prat, and Tommaso Valletti, "Active and Passive Waste in Government Spending: Evidence from a Policy Experiment," American Economic Review, 99 (2009), 1278-1308. Barro, Robert, "The Control of Politicians: An Economic Model," Public Choice, 14 (1973), 19-42. Besley, Timothy, and Anne Case, "Does Electoral Accountability Affect Economic Policy Choices? Evidence from Gubernatorial Term Limits," Quarterly Journal of Economics, 110 (1995), 769-798. Björkman, Martina, and Jakob Svensson, "Power to the People: Evidence from a Randomized Field Experiment on Community-based Monitoring in Uganda," Quarterly Journal of Economics, 124 (2009), 735-769.

Císařová Eliška, and Jan Pavel, Průvodce komunálními rozpočty aneb jak může informovaný občan střežit obecní pokladnu (Prague, Czech Republic: Transparency International, 2008).

Chang, Eric, and Miriam Golden, "Electoral Systems, District Magnitude and Corruption," British Journal of Political Science, 37 (2007), 15-137.

Di Tella, Rafael, and Ernesto Schargrodsky, "The Role of Wages and Auditing during a Crackdown on Corruption in the City of Buenos Aires," Journal of Law and Economics, 46 (2003), 269-292.

The Economist, "State Capture," Nov 2nd, 2011.

The Economist, "Bearer Beware," May 19th, 2013.

Faccio, Mara, “Politically Connected Firms," American Economic Review, 96 (2006), 369-386.

Ferejohn, John, "Incumbent Performance and Electoral Control," Public Choice, 50 (1986), 5-25.

Ferraz, Claudio, and Frederico Finan, "Exposing Corrupt Politicians: The Effect of Brazil's Publicly Released Audits on Electoral Outcomes," Quarterly Journal of Economics, 123 (2008), 703-745.

Ferraz, Claudio, and Frederico Finan, "Electoral Accountability and Corruption: Evidence from the Audits of Local Governments," American Economic Review, 101 (2011), 1274-1311.

Ferreira, Fernando, and Joseph Gyourko, "Do Political Parties Matter? Evidence from U.S. Cities," Quarterly Journal of Economics, 124 (2009), 399-422.

Fisman, Raymond, "Estimating the Value of Political Connections," American Economic Review, 91 (2001), 1095-1102. 
Folke, Olle, "Shades of Brown and Green: Party Effects in Proportional Election Systems," Journal of the European Economic Association, 12 (2014), 1361-1395.

Gagliarducci, Stefano, and Tommaso Nannicini, "Do Better Paid Politicians Perform Better? Disentangling Incentives from Selection," Journal of the European Economic Association, 11 (2013), 369-398.

Gordon, Sanford, and Gregory Huber, "The Effect of Electoral Competitiveness on Incumbent Behavior," Quarterly Journal of Political Science, 2 (2007), 107-138.

Gordon, Sanford, Gregory Huber, and Dimitri Landa, "Challenger Entry and Voter Learning," Americal Political Science Review, 101 (2007), 303-20.

Hahn, Jinyong, Petra Todd, and Wilbert van der Klaauw, "Identification and Estimation of Treatment Effects with a Regression Discontinuity Design," Econometrica, 69 (2001), 201-209.

Imbens, Guido, and Thomas Lemieux, "Regression discontinuity designs: A guide to practice," Journal of Econometrics, 142 (2008), 615-635.

Jacob, Brian, and Lars Lefgren, "Remedial Education and Student Achievement: A RegressionDiscontinuity Analysis," Review of Economics and Statistics, 86 (2004), 226-244.

Jurajda, Štěpán, and Daniel Münich, "Candidate Ballot Information and Election Outcomes: the Czech Case," Post-Soviet Affairs, (2014).

Khwaja, Asim ljaz, and Atif Mian, "Do Lenders Favor Politically Connected Firms? Rent Provision in an Emerging Financial Market," Quarterly Journal of Economics, 120 (2005), 1371-1411.

Kunicova, Jana, and Susan Rose-Ackerman, "Electoral Rules and Constitutional Structures as Constraints on Corruption," British Journal of Political Science, 35 (2005), 573-606.

Lee, David, "Randomized Experiments from Non-Random Selection in U.S. House Elections," Journal of Econometrics, 142 (2008), 675-697.

Lee, David, and Thomas Lemieux, "Regression Discontinuity Designs in Economics," Journal of Economic Literature, 48 (2010), 281-355.

Lee, David, Enrico Moretti, and Matthew Butler, "Do Voters Affect or Elect Policies? Evidence from the U.S. House," Quarterly Journal of Economics, 119 (2004), 807-860.

Manelli, Alejandro, and Daniel Vincent, "Optimal Procurement Mechanisms," Econometrica, 63 (1995), 591-620.

Manin, Bernard, Adam Przeworski, and Susan Stokes. Elections and Representation. In Democracy, Accountability, and Representation, ed. Adam Przeworski, Susan Stokes and Bernard Manin. (New York: Cambridge University Press, 1999).

McCrary, Justin, "Manipulation of the Running Variable in the Regression Discontinuity Design: A Density Test," Journal of Econometrics, 142 (2008), 698-714.

Mironov, Maxim, and Ekaterina Zhurasvkaya: "Corruption in Procurement and Shadow Campaign Financing: Evidence from Russia," mimeo.

Murphy, Kevin, Andrei Shleifer, and Robert Vishny, "The Allocation of Talent: Implications for Growth," Quarterly Journal of Economics, 106, (1991), 503-530. 
Murphy Kevin, Andrei Shleifer, and Robert Vishny, "Why Is Rent-Seeking So Costly to Growth?," American Economic Review, 83, (1993), 409-414.

OECD, Government at a Glance 2013 (Paris, France: OECD Publishing, 2013).

Olken, Ben, "Monitoring Corruption: Evidence from a Field Experiment in Indonesia," Journal of Political Economy, 115 (2007), 200-249.

Pavel, Ján, Veřejné zakázky a efektivnost, (Prague, Czech Republic: Ekopress, 2013).

Persson, Torsten, and Guido Tabellini. Political Economics: Explaining Economic Policy (Cambridge, Massachusetts: MIT Press, 2000).

Persson, Torsten, Gerard Roland, and Guido Tabellini, "Comparative Politics and Public Finance," Journal of Political Economy, 108 (2000), 1121-1161.

Persson, Torsten, Gerard Roland, and Guido Tabellini, "Electoral Rules and Government Spending in Parliamentary Democracies," Quarterly Journal of Political Science, 2 (2007), 155-188.

Persson, Torsten, Guido Tabellini, and Francesco Trebbi, "Electoral Rules and Corruption," Journal of the European Economic Association, 4 (2003), 958-989.

Pettersson-Lidbom, Per, "Do Parties Matter for Economic Outcomes? A Regression-Discontinuity Approach," Journal of European Economic Association, 6 (2008), 1037-1056.

Reinikka, Ritva, and Jakob Svensson, "Local Capture: Evidence from a Central Government Transfer Program in Uganda," Quarterly Journal of Economics, 119 (2004), 679-705.

Reinikka, Ritva, and Jakob Svensson, "Fighting Corruption to Improve Schooling: Evidence from a Newspaper Campaign in Uganda," Journal of the European Economic Association, 3 (2005), 259267.

Reinikka, Ritva, and Jakob Svensson, "The Power of Information in Public Services: Evidence from Education in Uganda," Journal of Public Economics, 95 (2011), 956-966.

Straub, Stephane: "Political Firms, Public Procurement, and the Democratization Process," TSE Working Papers no. 14-461, Toulouse School of Economics, 2014.

Tavits, Margit, "Clarity of Responsibility and Corruption," American Journal of Political Science, 51 (2007), 218-229.

Transparency International, Efektivnost Fungování Kontrolních Systemů Veřejných Zakázek $v$ České Republice (Prague, Czech Republic: Transparency International, 2009).

Transparency International, Corruption Perceptions Index 2012, (Berlin, Germany: Transparency International, 2012).

Trebbi, Francesco, Phillipe Aghion, and Alberto Alesina, "Choosing Electoral Rules: Theory and Evidence from US Cities," Quarterly Journal of Economics, 123 (2008), 325-357.

Van der Klaauw, Wilbert, "Estimating the Effect of Financial Aid Offers on College Enrollment: A Regression-Discontinuity Approach," International Economic Review, 43 (2002), 1249-1287.

World Economic Forum, The Global Competitiveness Report 2011-2012, (Geneva, Switzerland: World Economic Forum, 2011).

Zitzewitz, Eric, “Forensic Economics," Journal of Economic Literature, 50 (2012), 731-769. 


\section{Tables and Figures}

TABLE 1

Summary Statistics

\begin{tabular}{lrrrr}
\hline Variables: & Mean & S.D. & Min & Max \\
\hline Procurement outcomes & & & & \\
Procurement-related donations from suppliers & 16.35 & 46.88 & 0 & 650 \\
(ths. CZK) & -0.08 & 0.20 & -0.84 & 2.96 \\
Price savings in procurement & 19.50 & 19.69 & 5.59 & 292.15 \\
Planned size of procurement (mil. CZK) & 5.63 & 2.53 & 1 & 28 \\
Number of bidding suppliers & & & & \\
& & & & \\
Fiscal outcomes & 94.19 & 256.40 & 0.55 & $5,036.13$ \\
Annual municipal fiscal revenue (mil. CZK) & 95.39 & 266.25 & 0.52 & $5,222.74$ \\
Annual municipal fiscal expenditure (mil. CZK) & 0.01 & 0.13 & -0.46 & 1.49 \\
Annual municipal budget deficit & & & & \\
Control variables & & & & \\
Population size (in ths.) & 4.55 & 11.14 & 0.02 & 165.24 \\
\# of parties running for elections (per ths. capita) & 5.73 & 12.26 & 0.04 & 126.44 \\
\# of distributed seats in legislature & 13.75 & 6.30 & 5 & 47 \\
\# of members of electoral coalitions & 1.04 & 0.19 & 1 & 2 \\
Average age of elected representatives & 46.49 & 3.78 & 32.60 & 60.71 \\
\# of women among representatives & 3.33 & 1.98 & 0 & 14 \\
\# of politicians from national-level parties & 6.70 & 6.86 & 0 & 42 \\
\hline \hline
\end{tabular}

The fiscal outcomes and the planned procurement size are expressed in 2005 CZK prices. The fiscal outcomes are calculated as four-year averages. The price savings are defined as the difference between the contractual price of procurement and its planned value, expressed as a percentage of the latter. The budget deficit is expressed as the percentage of the annual municipal revenue. Percentages are expressed on a scale between 0 and 1. 
TABLE 2

Descriptive Results - Sample Restricted around the Entry Threshold

\begin{tabular}{|c|c|c|c|}
\hline Variables: & $\begin{array}{l}\text { Below } \\
\text { Threshold } \\
0.03,0.05] \\
(1)\end{array}$ & $\begin{array}{c}\text { Above } \\
\text { Threshold } \\
{[0.05,0.07]} \\
(2)\end{array}$ & $\begin{array}{l}\text { Difference in } \\
\text { Means } \\
(2)-(1)\end{array}$ \\
\hline \multicolumn{4}{|l|}{ Procurement outcomes } \\
\hline $\begin{array}{l}\text { Procurement-related political donations } \\
\text { (ths. CZK) }\end{array}$ & 46.21 & 26.32 & $-19.89 * *$ \\
\hline Price savings in procurement & -0.06 & -0.11 & $-.05 * *$ \\
\hline Planned size of procurement (mil. CZK) & 23.41 & 22.78 & -.63 \\
\hline Number of bidding suppliers & 5.99 & 6.43 & .44 \\
\hline \multicolumn{4}{|l|}{ Fiscal outcomes } \\
\hline Annual municipal fiscal revenue (mil. CZK) & 322.64 & 323.87 & 1.23 \\
\hline Annual municipal fiscal expenditure (mil. CZK) & 327.75 & 330.57 & 2.81 \\
\hline Annual municipal budget deficit & -0.00 & 0.003 & 0.003 \\
\hline \multicolumn{4}{|l|}{ Control variables } \\
\hline Population size (in ths.) & 15.26 & 14.80 & -.46 \\
\hline \# of distributed seats in legislature & 20.45 & 20.44 & -.00 \\
\hline \# of parties running for elections (per ths. capita) & 2.01 & 2.11 & .10 \\
\hline \# of members of electoral coalitions & 1.10 & 1.08 & -.02 \\
\hline Average age of representatives & 47.96 & 47.86 & -.10 \\
\hline \# of women among representatives & 4.60 & 4.32 & -.28 \\
\hline \# of politicians from national-level parties & 13.70 & 13.63 & -.07 \\
\hline
\end{tabular}

The price savings are defined as the difference between the contractual price of procurement and its planned value, expressed as a percentage of the latter. The budget deficit is expressed as the percentage of the annual municipal revenue. Percentages are expressed on a scale between 0 and 1 . 103 observations come from legislatures with some party scoring just below the threshold and 138 from legislatures with some party scoring just above the threshold. The differences in means are tested using one-sample two-group t-tests, ${ }^{* * *} p<0.01,{ }^{* *} p<0.05,{ }^{*} p<0.1$. 


\section{TABLE 3}

Main Results - Parametric 2SLS Approach

\begin{tabular}{|c|c|c|c|c|c|c|c|}
\hline \multirow[b]{2}{*}{$\begin{array}{l}\text { Dependent } \\
\text { variables: }\end{array}$} & \multicolumn{4}{|c|}{ Public Procurement Outcomes } & \multicolumn{3}{|c|}{ Fiscal Outcomes } \\
\hline & $\begin{array}{c}\text { Procureme- } \\
\text { nt-related } \\
\text { political } \\
\text { donations } \\
\text { (ths. CZK) }\end{array}$ & $\begin{array}{c}\text { Price } \\
\text { savings }\end{array}$ & $\begin{array}{c}\text { Log } \\
\text { (Planned } \\
\text { contract } \\
\text { Size) }\end{array}$ & $\begin{array}{c}\text { Log } \\
\text { (Number } \\
\text { of bidding } \\
\text { suppliers) }\end{array}$ & $\begin{array}{c}\text { Log } \\
\text { (Budget } \\
\text { revenue) }\end{array}$ & $\begin{array}{l}\text { Log } \\
\text { (Budget } \\
\text { expendit } \\
\text {-ure) }\end{array}$ & $\begin{array}{l}\text { Budget } \\
\text { deficit }\end{array}$ \\
\hline & (1) & $(2)$ & (3) & (4) & (5) & (6) & (7) \\
\hline $\begin{array}{l}\text { Second stage: } \\
\text { Challenger } \\
\text { Wins } \geq 1 \\
\text { Seats }\end{array}$ & $\begin{array}{c}-29.226 * * \\
{[14.728]}\end{array}$ & $\begin{array}{c}-0.068 * \\
{[0.039]}\end{array}$ & $\begin{array}{c}-0.124 \\
{[0.124]}\end{array}$ & $\begin{array}{l}0.129 * \\
{[0.078]}\end{array}$ & $\begin{array}{c}-0.054 \\
{[0.071]}\end{array}$ & $\begin{array}{c}-0.047 \\
{[0.075]}\end{array}$ & $\begin{array}{c}0.006 \\
{[0.019]}\end{array}$ \\
\hline $\begin{array}{l}\text { Order of the } \\
\text { Control } \\
\text { Function }\end{array}$ & Fifth & Fifth & Fifth & Fifth & Fifth & Fifth & Fifth \\
\hline Covariates & Yes & Yes & Yes & Yes & Yes & Yes & Yes \\
\hline First stage: & & & & & & & \\
\hline $1[$ Vote_sh $\geq c]$ & $\begin{array}{c}0.694 * * * \\
{[0.044]}\end{array}$ & $\begin{array}{c}0.694 * * * \\
{[0.044]}\end{array}$ & $\begin{array}{c}0.694 * * * \\
{[0.044]}\end{array}$ & $\begin{array}{c}0.694 * * * \\
{[0.044]}\end{array}$ & $\begin{array}{c}0.694^{* * *} \\
{[0.044]}\end{array}$ & $\begin{array}{c}0.694 * * * \\
{[0.044]}\end{array}$ & $\begin{array}{c}0.694 * * * \\
{[0.044]}\end{array}$ \\
\hline$R^{2}$ & 0.514 & 0.514 & 0.514 & 0.514 & 0.513 & 0.513 & 0.513 \\
\hline Adj. $R^{2}$ & 0.477 & 0.477 & 0.477 & 0.476 & 0.475 & 0.475 & 0.475 \\
\hline Observations & 1,198 & 1,198 & 1,198 & 1,197 & 1,196 & 1,196 & 1,196 \\
\hline
\end{tabular}

Each column is a separate regression estimated on our whole sample using 2 SLS outlined in equations (2) and (3). The regressions also include, but do not report, dummy variables for 73 Czech geographical districts. Robust s.e. are in brackets, ${ }^{* * *} p<0.01,{ }^{* *} p<0.05,{ }^{*} p<0.1$. 
TABLE 4

Semi-parametric Approach

\begin{tabular}{|c|c|c|c|c|c|c|c|}
\hline \multirow[b]{2}{*}{$\begin{array}{l}\text { Dependent } \\
\text { variables: }\end{array}$} & \multicolumn{4}{|c|}{ Public Procurement Outcomes } & \multicolumn{3}{|c|}{ Fiscal Outcomes } \\
\hline & $\begin{array}{c}\text { Procureme- } \\
\text { nt-related } \\
\text { political } \\
\text { donations } \\
\text { (CZK ths.) }\end{array}$ & $\begin{array}{c}\text { Price } \\
\text { savings }\end{array}$ & $\begin{array}{c}\text { Log } \\
\text { (Planned } \\
\text { contract } \\
\text { size) }\end{array}$ & $\begin{array}{c}\text { Log } \\
\text { (Number } \\
\text { of bidding } \\
\text { suppliers) }\end{array}$ & $\begin{array}{l}\text { Log } \\
\text { (Budget } \\
\text { revenue) }\end{array}$ & $\begin{array}{l}\text { Log } \\
\text { (Budget } \\
\text { expendi- } \\
\text { ture) }\end{array}$ & $\begin{array}{l}\text { Budget } \\
\text { deficit }\end{array}$ \\
\hline Second stage: & (1) & (2) & (3) & (4) & (5) & (6) & (7) \\
\hline Challenger & $-26.394 *$ & $-0.065^{*}$ & -0.076 & $0.123 *$ & -0.293 & -0.289 & 0.003 \\
\hline Wins $\geq 1$ Seats & [13.835] & {$[0.036]$} & {$[0.106]$} & {$[0.070]$} & {$[0.241]$} & {$[0.243]$} & [0.013] \\
\hline Order of CF & None & None & None & None & None & None & None \\
\hline Covariates & No & No & No & No & No & No & No \\
\hline $\begin{array}{l}\text { Around the } \\
\text { Threshold }\end{array}$ & $+/-2 p p$ & $+/-2 p p$ & $+/-2 p p$ & $+/-2 p p$ & $+/-2 p p$ & $+/-2 p p$ & $+/-2 p p$ \\
\hline Observations & 241 & 241 & 241 & 241 & 240 & 240 & 240 \\
\hline
\end{tabular}

Each column is a separate regression estimated using 2 SLS outlined in equations (2) and (3). Only observations with the partisan vote share within the range of [03-07] \% are included. Robust standard errors are in brackets, ${ }^{* * *} p<0.01,{ }^{* *} p<0.05,{ }^{*} p<0.1$. 


\section{TABLE 5}

Control Funcion Specification

\begin{tabular}{|c|c|c|c|c|}
\hline \multicolumn{5}{|c|}{ Panel A. Procurement Outcomes } \\
\hline Specification: & (1) & $(2)$ & (3) & (4) \\
\hline $\begin{array}{l}\text { Procurement-related political } \\
\text { donations (CZK ths.) }\end{array}$ & $\begin{array}{c}-22.704^{* *} \\
{[11.595]}\end{array}$ & $\begin{array}{l}-26.129 * \\
{[13.534]}\end{array}$ & $\begin{array}{c}-29.226 * * \\
{[14.728]}\end{array}$ & $\begin{array}{l}-29.896^{*} \\
{[17.422]}\end{array}$ \\
\hline Price savings in procurement & $\begin{array}{l}-0.051 \\
{[0.035]}\end{array}$ & $\begin{array}{l}-0.069 * \\
{[0.039]}\end{array}$ & $\begin{array}{l}-0.068 * \\
{[0.039]}\end{array}$ & $\begin{array}{l}-0.085^{*} \\
{[0.044]}\end{array}$ \\
\hline Log (Planned Contract Size) & $\begin{array}{l}-0.075 \\
{[0.105]}\end{array}$ & $\begin{array}{l}-0.065 \\
{[0.120]}\end{array}$ & $\begin{array}{l}-0.124 \\
{[0.124]}\end{array}$ & $\begin{array}{l}-0.120 \\
{[0.144]}\end{array}$ \\
\hline Log (Number of Bidding Suppliers) & $\begin{array}{c}0.066 \\
{[0.064]}\end{array}$ & $\begin{array}{c}0.067 \\
{[0.075]}\end{array}$ & $\begin{array}{l}0.129 * \\
{[0.078]}\end{array}$ & $\begin{array}{c}0.189 * * \\
{[0.090]}\end{array}$ \\
\hline Sample & Full & Full & Full & Full \\
\hline Covariates & Yes & Yes & Yes & Yes \\
\hline Order of the CF & Third & Fourth & Fifth & Sixth \\
\hline \multicolumn{5}{|c|}{ Panel B. Fiscal Outcomes } \\
\hline Specification: & $(1)$ & $(2)$ & (3) & $(4)$ \\
\hline Log (Budget revenue) & $\begin{array}{l}-0.088 \\
{[0.057]}\end{array}$ & $\begin{array}{l}-0.082 \\
{[0.066]}\end{array}$ & $\begin{array}{l}-0.054 \\
{[0.071]}\end{array}$ & $\begin{array}{l}-0.048 \\
{[0.082]}\end{array}$ \\
\hline Log (Budget expenditure) & $\begin{array}{l}-0.090 \\
{[0.061]}\end{array}$ & $\begin{array}{l}-0.069 \\
{[0.071]}\end{array}$ & $\begin{array}{l}-0.047 \\
{[0.075]}\end{array}$ & $\begin{array}{l}-0.021 \\
{[0.088]}\end{array}$ \\
\hline Budget deficit & $\begin{array}{l}-0.002 \\
{[0.016]}\end{array}$ & $\begin{array}{c}0.014 \\
{[0.018]}\end{array}$ & $\begin{array}{c}0.006 \\
{[0.019]}\end{array}$ & $\begin{array}{c}0.027 \\
{[0.022]}\end{array}$ \\
\hline Sample & Full & Full & Full & Full \\
\hline Covariates & Yes & Yes & Yes & Yes \\
\hline Order of the CF & Third & Fourth & Fifth & Sixth \\
\hline
\end{tabular}

Each entry is a separate regression estimated using 2 SLS outlined in equations (2) and (3). Robust standard errors are presented in brackets, ${ }^{* * *} p<0.01,{ }^{* *} p<0.05,{ }^{*} p<0.1$ 
TABLE 6

Is the Vote Share Near the Threshold as Well as Randomly Assigned?

\begin{tabular}{lr}
\hline \hline Dependent variable: & \\
Indicator that challenger's vote share exceeds the electoral threshold \\
\hline Log (population) & $0.016[0.014]$ \\
\# of distributed seats in legislature & $0.119[0.502]$ \\
\# of parties running for elections & $-0.002[0.002]$ \\
\# of electoral coalition members & $0.002[0.045]$ \\
Average age of representatives & $0.001[0.001]$ \\
\# of woman representatives & $-0.005[0.004]$ \\
\# of representatives from national-level parties & $0.000[0.002]$ \\
F - test & 0.92 \\
$p$ - value & 0.492 \\
Observations & 1,198 \\
\hline \hline
\end{tabular}

The OLS regression also includes, but does not report, the coefficients on the quintic control function and district dummies. Robust standard errors are in brackets. ${ }^{* *} p<0.01,{ }^{* *} p<0.05,{ }^{*} p<0.1$

TABLE 7

McCrary's Density Discontinuity Test

\begin{tabular}{lcc}
\hline \hline & $\begin{array}{c}\text { The Vote Share - All } \\
\text { Parties }\end{array}$ & $\begin{array}{c}\text { The Vote Share of } \\
\text { Parties Closest to } \\
5 \%\end{array}$ \\
\hline Discontinuity Estimate & -.150 & -.181 \\
Observations & {$[.119]$} & {$[.190]$} \\
\hline
\end{tabular}

Standard errors are given in brackets. ${ }^{* * *} p<0.01,{ }^{* *} p<0.05, * p<0.1$ 


\section{TABLE 8}

Placebo Tests of Whether the Entry of Challengers Can Predict Pre-determined Covariates

\begin{tabular}{lcccccc} 
Dependent & Log & A & \# of & Avg. & \# of & \# of \\
variables: & (Popula- & \# of seats in \\
tion) & legislatures & $\begin{array}{c}\text { \# of } \\
\text { parties in } \\
\text { elections }\end{array}$ & $\begin{array}{c}\text { members } \\
\text { in electoral } \\
\text { coalition }\end{array}$ & $\begin{array}{c}\text { age of } \\
\text { reps }\end{array}$ & $\begin{array}{c}\text { woman } \\
\text { reps }\end{array}$ & $\begin{array}{c}\text { national } \\
\text { reps }\end{array}$ \\
\hline \hline
\end{tabular}

\begin{tabular}{|c|c|c|c|c|c|c|c|}
\hline Second stage: & (1) & $(2)$ & (3) & (4) & (5) & (6) & (7) \\
\hline $\begin{array}{l}\text { Challenger } \\
\text { Wins } \geq 1 \text { Seats }\end{array}$ & $\begin{array}{c}0.291 \\
{[0.231]}\end{array}$ & $\begin{array}{c}-0.002 \\
{[0.001]}\end{array}$ & $\begin{array}{c}-0.568 \\
{[0.461]}\end{array}$ & $\begin{array}{c}0.005 \\
{[0.053]}\end{array}$ & $\begin{array}{c}0.575 \\
{[0.601]}\end{array}$ & $\begin{array}{c}-0.265 \\
{[0.442]}\end{array}$ & $\begin{array}{c}1.207 \\
{[1.550]}\end{array}$ \\
\hline $\begin{array}{l}\text { Sample } \\
\text { Order of CF }\end{array}$ & $\begin{array}{l}\text { Full } \\
\text { Fifth }\end{array}$ & $\begin{array}{l}\text { Full } \\
\text { Fifth }\end{array}$ & $\begin{array}{l}\text { Full } \\
\text { Fifth }\end{array}$ & $\begin{array}{l}\text { Full } \\
\text { Fifth }\end{array}$ & $\begin{array}{l}\text { Full } \\
\text { Fifth }\end{array}$ & $\begin{array}{l}\text { Full } \\
\text { Fifth }\end{array}$ & $\begin{array}{l}\text { Full } \\
\text { Fifth }\end{array}$ \\
\hline First stage: & & & & & & & \\
\hline 1 [Vote_sh $\geq c]$ & $\begin{array}{l}.729 * * * \\
{[0.045]}\end{array}$ & $\begin{array}{l}.729 * * * \\
{[0.045]}\end{array}$ & $\begin{array}{l}.729 * * * \\
{[0.045]}\end{array}$ & $\begin{array}{l}.729 * * * \\
{[0.045]}\end{array}$ & $\begin{array}{l}.729 * * * \\
{[0.045]}\end{array}$ & $\begin{array}{l}.729 * * * \\
{[0.045]}\end{array}$ & $\begin{array}{l}.729 * * * \\
{[0.045]}\end{array}$ \\
\hline $\mathrm{R}^{2}$ & 0.320 & 0.320 & 0.320 & 0.320 & 0.320 & 0.320 & 0.320 \\
\hline Adj. $R^{2}$ & 0.316 & 0.316 & 0.316 & 0.316 & 0.316 & 0.316 & 0.316 \\
\hline Observations & 1,198 & 1,198 & 1,198 & 1,198 & 1,198 & 1,198 & 1,198 \\
\hline
\end{tabular}

Each column is a separate 2 SLS regression, which includes a quintic control function. Robust standard errors are presented in brackets. ${ }^{* *} p<0.01,{ }^{* *} p<0.05, * p<0.1$ 


\section{TABLE 9}

Heterogenous Importance of the Entry of Political Challengers

\begin{tabular}{lcccc}
\hline Dependent variables: & $\begin{array}{c}\text { Procurement- } \\
\text { related political } \\
\text { donations (ths. } \\
\text { CZK) }\end{array}$ & $\begin{array}{c}\text { Procurement } \\
\text { price } \\
\text { rebates }\end{array}$ & $\begin{array}{c}\text { Log (Planned } \\
\text { procurement } \\
\text { size) }\end{array}$ & $\begin{array}{c}\text { Log (Number } \\
\text { of bidding } \\
\text { suppliers) }\end{array}$ \\
\hline \hline Panel A & $(1)$ & $(2)$ & $(3)$ & $(4)$ \\
(Challenger Wins $\geq 1$ & $-3.860^{* *}$ & $-0.009^{*}$ & -0.016 & $0.017^{*}$ \\
Seats) * \# of Parties) & {$[1.944]$} & {$[0.005]$} & {$[0.016]$} & {$[0.010]$} \\
Sample & Full & Full & Full & Full \\
\hline \hline Panel B & $(1)$ & $(2)$ & $(3)$ & $(4)$ \\
(Challenger Wins $\geq 1$ & $-3.094^{* *}$ & $-0.007^{*}$ & -0.013 & $0.014^{*}$ \\
Seats) * Log(Population) & {$[1.551]$} & {$[0.004]$} & {$[0.013]$} & {$[0.008]$} \\
Sample & Full & Full & Full & Full \\
\hline \hline Panel C & $(1)$ & $(2)$ & $(3)$ & $(4)$ \\
Challenger Wins $\geq 1$ & $-42.268^{*}$ & -0.062 & -0.180 & 0.038 \\
Seats & {$[22.545]$} & {$[0.053]$} & {$[0.158]$} & {$[0.090]$} \\
Sample & Local-level & Local-level & Local-level & Local-level \\
& challengers & challengers & challengers & challengers \\
\hline \hline Panel D & $(1)$ & $(2)$ & $(3)$ & $(4)$ \\
Challenger Wins $\geq 1$ & -13.132 & -0.077 & 0.046 & $0.251^{*}$ \\
Seats & {$[14.912]$} & {$[0.060]$} & {$[0.208]$} & {$[0.144]$} \\
Sample & National-level & National-level & National-level & National-level \\
& challengers & challengers & challengers & challengers \\
\hline \hline
\end{tabular}

Each entry is a separate 2SLS regression. The regressions include, but do not report, the quintic control function ( $q=5$ ) and a set of covariates. The restricted sample with the local-level challengers includes 614 observations where the political party closest to the threshold is a local-level party. The sample with the national-level challengers includes 584 observations where the party closest to the threshold is a national-level party. Robust s.e. are in brackets, ${ }^{* *} p<0.01,{ }^{* *} p<0.05,{ }^{*} p<0.1$. 


\section{FIGURE 1}

The Relationship between the Vote Share and Entry into Legislatures
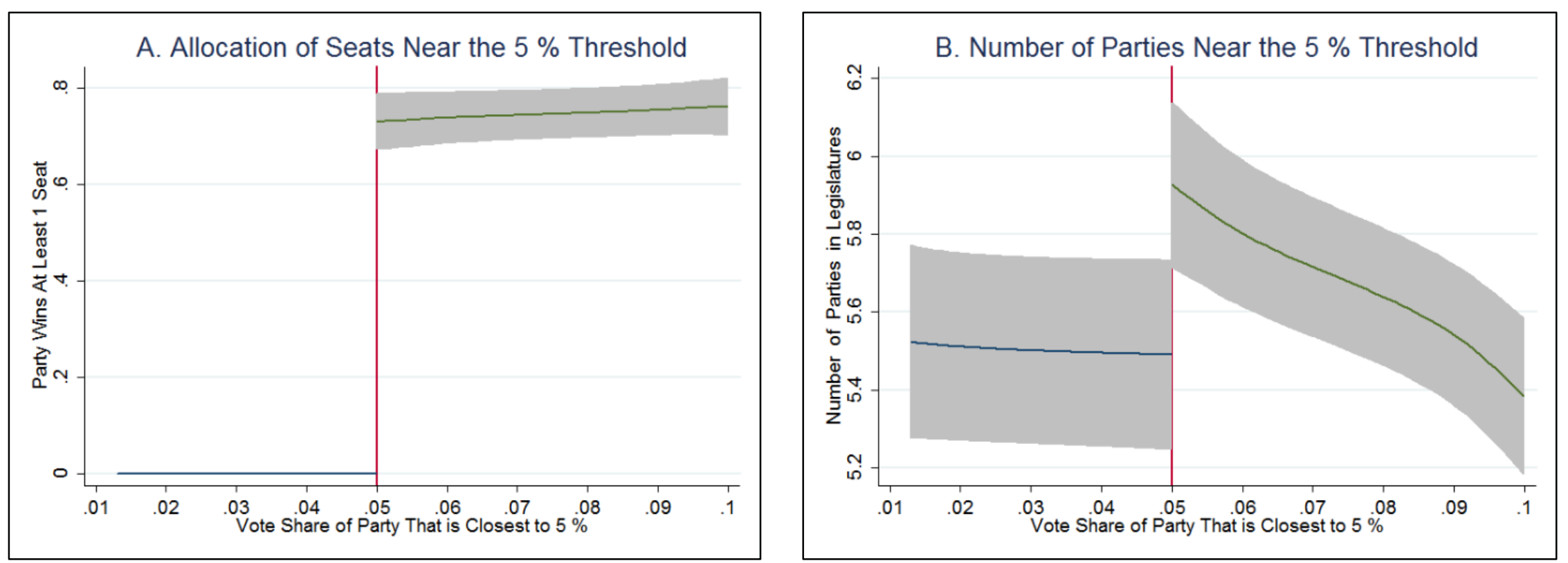

The left subfigure shows the probability of winning at least one seat in the legislature when a party closest in the legislature exceeds the electoral threshold. The right subfigure shows the overall number of parties with seats as a function of the vote share of a party closest to the electoral threshold. The grey areas are the $95 \%$ confidence intervals. 
FIGURE 2

Discontinuities in the Procurement and Fiscal Outcomes

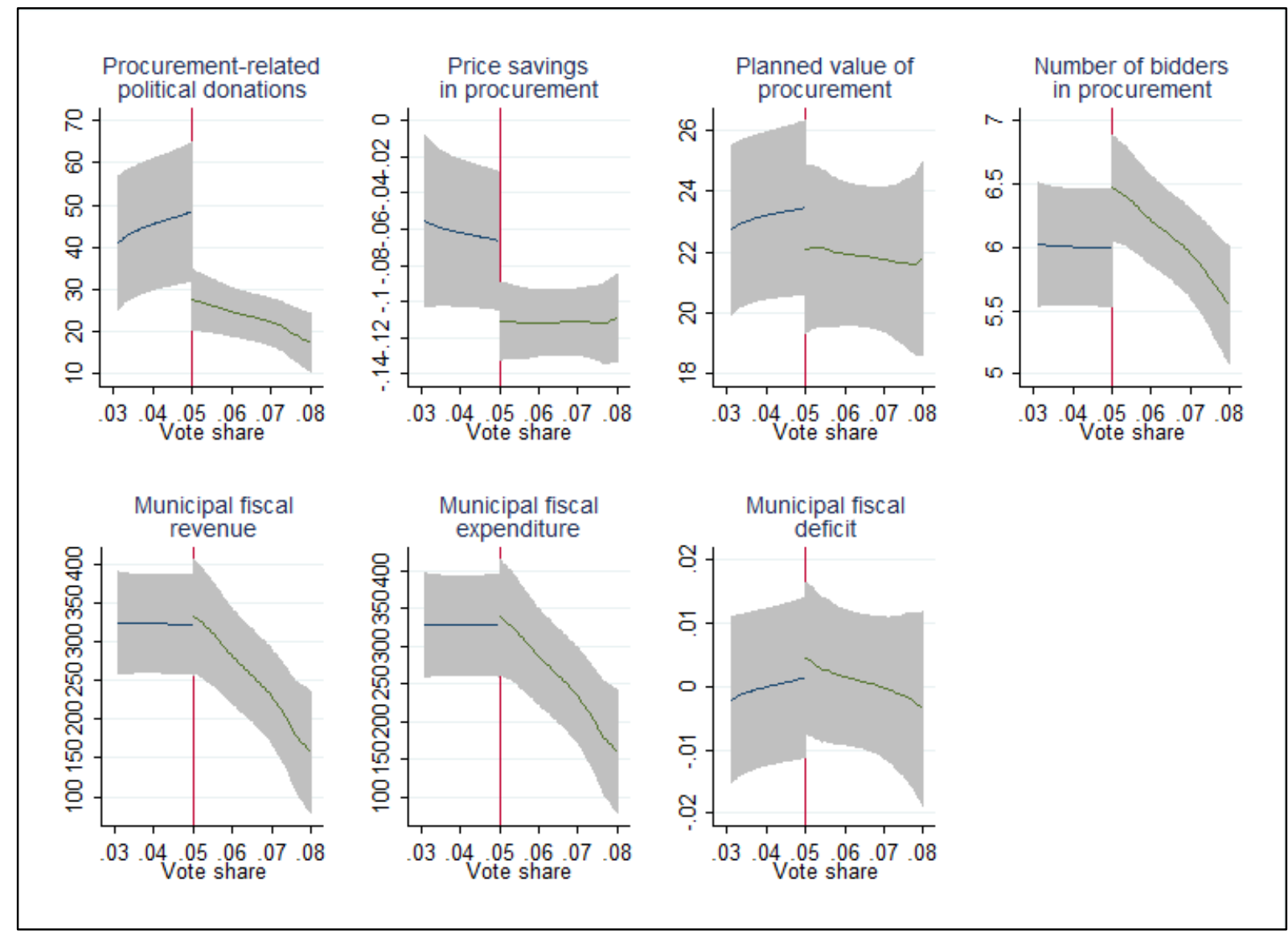

The variable on the horizontal axis is the vote share of the political subjects that scored the closest to the electoral threshold in a given municipality. The grey areas are the $90 \%$ confidence intervals, unadjusted for the actual entry of political challengers into legislatures. 
FIGURE 3

\section{Discontinuities in the Pre-Determined Covariates}

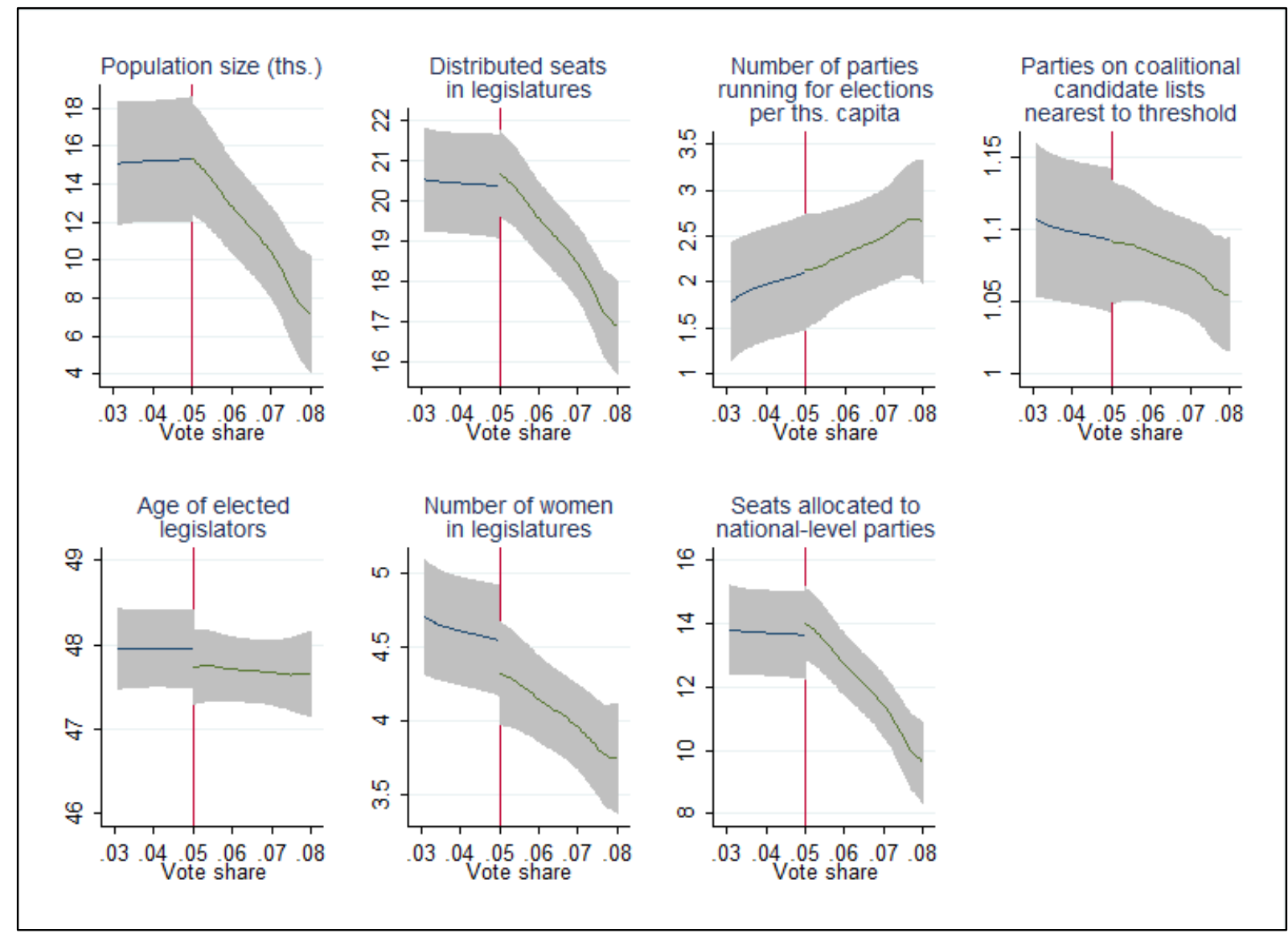

The variable on the horizontal axis is the vote share of the political party that scored the closest to the electoral threshold in a given municipality. The grey areas are the $90 \%$ confidence intervals, unadjusted for the actual entry of political challengers into legislatures. 


\begin{abstract}
Abstrakt
Článek ukazuje, že vstup další politické strany do obecního zastupitelstva posiluje politickou odpovědnost zastupitelů a omezuje dolování renty ve veřejných zakázkách. Článek predikuje nenáhodný vstup stran do zastupitelstev pomocí informace o překročení 5\% volebního limitu v poměrném volebním systému. Na datech ze zastupitelstev obcí v České republice článek prokazuje, že zastupitelé zadávají menší počet veřejných zakázek sponzorům politických stran, když do zastupitelstva vstoupí dodatečná politická strana. Zároveň se zdvojnásobí cenové úspory v zakázkách a ty se otevřou většímu počtu firem. Vstup další strany přináší větší benefity tam, kde jsou motivace pro vzájemné monitorování se politiků silnější, jako např́klad v menších zastupitelstvech nebo v zastupitelstvech s menším počtem stran. Mé výsledky podtrhují roli lokálních politických uskupení pro vynucování politické odpovědnosti a význam informací o jednání politiků v zastupitelstvech.
\end{abstract}




\section{Working Paper Series}

ISSN 1211-3298

Registration No. (Ministry of Culture): E 19443

Individual researchers, as well as the on-line and printed versions of the CERGE-EI Working Papers (including their dissemination) were supported from institutional support RVO 67985998 from Economics Institute of the ASCR, v. v. i.

Specific research support and/or other grants the researchers/publications benefited from are acknowledged at the beginning of the Paper.

(c) Ján Palguta, 2015

All rights reserved. No part of this publication may be reproduced, stored in a retrieval system or transmitted in any form or by any means, electronic, mechanical or photocopying, recording, or otherwise without the prior permission of the publisher.

Published by

Charles University in Prague, Center for Economic Research and Graduate Education (CERGE) and

Economics Institute of the ASCR, v. v. i. (EI)

CERGE-El, Politických vězňů 7, 11121 Prague 1, tel.: +420 224005 153, Czech Republic.

Printed by CERGE-EI, Prague

Subscription: CERGE-EI homepage: http://www.cerge-ei.cz

Phone: + 420224005153

Email: office@cerge-ei.cz

Web: http://www.cerge-ei.cz

Editor: Marek Kapička

The paper is available online at http://www.cerge-ei.cz/publications/working_papers/.

ISBN 978-80-7343-356-7 (Univerzita Karlova v Praze, Centrum pro ekonomický výzkum a doktorské studium)

ISBN 978-80-7344-351-1 (Národohospodářský ústav AV ČR, v. v. i.) 
CERGE-EI

P.O.BOX 882

Politických vězňů 7

11121 Praha 1

Czech Republic http://www.cerge-ei.cz 